\title{
PENERAPAN MODEL PEMBELAJARAN COOPERATIVE LEARNING TIPE JIGSAW II UNTUK MENINGKATKAN AKTIVITAS DAN HASIL BELAJAR SISWA PADA MATA PELAJARAN DASAR TEKNIK MESIN (Penelitian Tindakan Kelas Pada Mata Pelajaran Dasar Teknik Mesin Kelas XTP1 di SMKN 6 Bandung)
}

\author{
Syafarudin Siregar ${ }^{1}$, Uli Karo Karo ${ }^{2}$, Tommy Eka Rahmadani ${ }^{3}$
}

\begin{abstract}
Abstrak: Tujuan penelitian ini adalah untuk meningkatkan aktivitas dan hasil belajar siswa pada mata pelajaran Dasar Teknik Mesin menggunakan model Cooperative Learning tipe Jigsaw II pada siswa kelas XTP1 SMK Negeri 6 Bandung. Metode penelitian yang digunakan ialah penelitian tindakan kelas (PTK) yang terdiri dari tiga siklus. Penelitian ini dilaksanakan dengan pembelajaran diawali dengan pretest dan diakhiri dengan post test setiap siklusnya. Hasil penelitian yang diperoleh menunjukan peningkatan aktivitas siswa untuk setiap siklusnya. Hasil rata-rata aktivitas kelompok spesialis untuk setiap siklusnya sbb; siklus I 44.16\% (sedang), meningkat pada siklus II menjadi 56.83\% (sedang), Siklus III menjadi $86 \%$ (sangat tinggi). kemudian hasil rata-rata aktivitas kelompok asal untuk setiap siklusnya sbb; siklusI $37.5 \%$, meningkat pada siklus II menjadi 69.79\% (tinggi), meningkat lagi pada siklus III menjadi $93.83 \%$ (sangat tinggi). dari aktivitas tersebut mempengaruhi hasil belajar siswa pada setiap siklus pembelajaran, terutama hasil skor pretes dan posttest; siklus I pretest 48.91 dan posttest 63.78 (meningkat 14.87), Siklus II pretest 61.89 dan posttest 78.78 (meningkat 16.89), siklus III pretest 72.56 dan posttest 86.89 (meningkat 14.33). Berdasarkan analisis data hasil penelitian yang diperoleh di lapangan maka dapat disimpulkan bahwa penerapan model pembelajaran Cooperative Learning Tipe Jigsaw II dapat meningkatkan aktivitas dan hasil belajar siswa pada mata pelajaran Dasar Teknik Mesin pada siswa kelas XTP1 SMK Negeri 6 Bandung.
\end{abstract}

\begin{abstract}
The purpose of this research is to develop activities and result student learning outcomes in Mechanical Engineering Basic using Cooperative Learning Model Type Jigsaw II on XTP1 students at SMKN 6 Bandung. Research method used is the Classroom Action Research (CAR) which consists of three cycles. The study conducted by learning begins with pretest and posttest each cycle. Average yield for the specialist group activity each cycle as follows: Cycle I $44.16 \%$ (being), increase in cycle II to $56.83 \%$ (being), cycle III to $86 \%$ (very high). Then the average home group activity for each cycle as follows: cycle I $37.5 \%$, increase in cycle II to $69.79 \%$ (high). Increased again the third cycle to $93.83 \%$ (very High). From the activity affect students' learning result in each cycle of learning, especially pretest result and posttest scores : pretest cycle I 48.91 and posttest 63.78 (up 14.84). 61.89 cycle II pretest and posttest 78.78 (up 16.89), 72.56 cycle III pretest and posttest 86.89 (up 14.33). Based on Analysis of research data obtained in the field I nt can be concluded that the application of Cooperation Learning Model Type Jigsaw II can be increase the activity learning and learning result outcomes in subject Mechanical Engineering Basic of XTP1 at SMKN 6 Bandung.
\end{abstract}

Kata Kunci : Model Pembelajaran Cooperative, Jigsaw II, Aktivitas Belajar, Hasil Belajar, Mata Pelajaran Dasar Teknik Mesin

\section{PENDAHULUAN}

SMK Negeri 6 Bandung sebagai salah satu Sekolah Berstandar Internasional yang memiliki sertifikat ISO 9001:2008 telah menetapkan Kriteria Ketuntasan Minimal (KKM) untuk semua pelajaran, termasuk didalamnya pelajaran Produktif. Untuk mata pelajaran produktif Teknik Pemesinan (TP) ditetapkan dengan $\mathrm{KKM} \geq 70$.
Meskipun KKM telah ditetapkan namun pada kenyataannya dalam mata pelajaran produktif, terutama mata pelajaran Dasar Teknik Mesin, siswa belum mampu untuk mencapai batas KKM yang telah ditetapkan tersebut. Hanya sekitar \pm 56 $\%$ saja siswa yang dikatakan memenuhi nilai KKM.

\footnotetext{
${ }^{1}$ Drs. H. Syafarudin Siregar, M.Pd adalah Dosen Jurusan Pendidikan Teknik Mesin FPTK UPI

${ }^{2}$ Drs. Uli Karo Karo, M.Pd adalah Dosen Jurusan Pendidikan Teknik Mesin FPTK UPI

${ }^{3}$ Tommy Eka R, adalah Mahasiswa JPTM FPTK UPI
} 
Tabel 1.1.

Nilai Mata Pelajaran Dasar Teknik Mesin (DTM) Peserta Diklat Kelas X TP 1 di SMK Negeri 6 Bandung

\begin{tabular}{|c|c|c|c|c|}
\hline No. & Nilai & Keterangan & Frekuensi & $\begin{array}{c}\text { Prosentase } \\
(\%)\end{array}$ \\
\hline 1 & $90-100$ & Sangat Baik & - & - \\
\hline 2 & $80-89$ & baik & 8 & 21.62 \\
\hline 3 & $70-79$ & Cukup & 13 & 35.13 \\
\hline 4 & $0<70$ & Belum lulus & 16 & 43.24 \\
\hline \multicolumn{3}{|c|}{ Jumlah } & 37 & 100 \\
\hline
\end{tabular}

(Sumber: Dokumen guru mata pelajaran)

Melihat data tersebut diatas jelas bahwa nilai untuk mata pelajaran Dasar Teknik Mesin (DTM) sangat kurang, dimana siswa yang dapat memenuhi kriteria KKM hanya sekitar $\pm 56 \%$ saja. Ada beberapa faktor yang dapat penulis tangkap dari data tersebut, dan dijadikan identifikasi masalah diantaranya adalah : (1) Proses pembelajaran yang berlangsung lebih berorientasi ke teacher centered ketimbang student centered, seperti metode ceramah yang sering digunakan, sehingga membuat siswa kurang aktif dalam proses pembelajaran. (2) Proses pembelajaran yang dilaksanakan cenderung monoton sehingga motivasi belajar siswa kurang, siswa pasif, dan kurang terbiasa dalam berinteraksi sosial dengan guru atau teman sekelasnya. (3) Perlu adanya alternatif model pembelajaran lain yang dapat meningkatkan kemampuan penguasaan materi dan komunikasi siswa di kelas dalam mata pelajaran Dasar Teknik Mesin.

Proses pembelajaran dalam Kurikulum Tingkat Satuan Pendidikan (KTSP) menuntut adanya partisipasi aktif dari seluruh siswa. Kegiatan belajar berpusat pada siswa, guru sebagai motivator dan fasilitator di dalamnya agar suasana kelas lebih hidup. Hal ini penulis anggap sangat bersinergi dengan metoda pembelajaran yang akan penulis coba terapkan yaitu teknik Cooperative Learning Tipe Jigsaw II. Dimana dalam pengimplementasiannya metoda ini membutuhkan peran aktif dari siswa untuk dapat mengikuti dan menerima pelajaran yang akan diperolehnya. Metoda ini juga menuntut siswa untuk dapat bekerja sama sebagai tim maupun individual. Pembelajaran kooperatif terutama teknik Jigsaw II merupakan bentuk adaptasi Jigsaw yang lebih praktis dan mudah, serta dianggap cocok diterapkan dalam pendidikan di Indonesia.

\section{TUJUAN PENELITIAN}

Tujuan umum penelitian ini adalah untuk meningkatkan aktivitas dan hasil belajar siswa pada mata pelajaran Dasar Teknik Mesin menggunakan model Cooperative Learning tipe Jigsaw II pada siswa kelas XTP1 SMK Negeri 6 Bandung. Sedangkan tujuan khusus dari penelitian ini adalah:

1 Untuk Mendeskripsikan apakah bentuk kegiatan pembelajaran dengan model cooperative learning tipe Jigsaw II dapat meningkatkan kemampuan pemahaman siswa pada mata pelajaran Dasar Teknik Mesin.

2 Untuk mengetahui seberapa besar peningkatan aktivitas siswa setelah mengikuti pembelajaran dengan model Cooperative learning tipe jigsaw II pada mata pelajaran Dasar Teknik Mesin.

3 Untuk mengetahui seberapa besar peningkatan kemampuan pemahaman siswa terhadap mata pelajaran Dasar Teknik Mesin setelah melakukan kegiatan pembelajaran melalui model Cooperative Learning tipe Jigsaw II yang tertuang dalam nilai hasil belajar (pretest dan posttest).

\section{MANFAAT PENELITIAN}

Penelitian terhadap penerapan model Cooperative Learning tipe Jigsaw II ini, diharapkan memberikan manfaat antara lain sebagai berikut:

1. Bagi guru, hasil penelitian ini dapat digunakan sebagai pertimbangan untuk menerapkan model cooperative learning pada mata pelajaran dasar teknik mesin atau mata pelajaran yang lain sebagai alternatif model pembelajaran lain.

2. Bagi siswa, penelitian ini memberikan kesempatan siswa untuk lebih aktif dan membentuk rasa tanggung jawab baik 
individu maupun kelompok dalam kegiatan pembelajaran.

3. Bagi peneliti, selain untuk menambah wawasan dan keterampilan dalam menerapkan model pembelajaran pada kegiatan belajar mengajar tetapi juga sebagai tindakan berpikir ilmiah untuk memperbaiki proses pembelajaran serta memecahkan masalah proses pembelajaran yang efektif dan efisien khususnya dalam mata pelajaran Dasar Teknik Mesin.

4. Bagi sekolah, penelitian ini diharapkan dapat memberikan kontribusi dalam upaya meningkatkan mutu, kualitas pembelajaran di Sekolah serta pengembangan kurikulum dalam menggunakan metode pembelajaran, khususnya pada mata Pelajaran Dasar Teknik Mesin dan mata pelajaran lain pada umumnya.

\section{PERTANYAAN PENELITIAN} adalah :

Pertanyaan penelitian dalam penelitian ini

1 Bagaimana bentuk kegiatan pembelajaran dengan model cooperative learning tipe Jigsaw II agar dapat meningkatkan kemampuan pemahaman siswa pada mata pelajaran Dasar Teknik Mesin?

2 Bagaimana peningkatan aktivitas siswa setelah mengikuti pembelajaran dengan model Cooperative learning tipe jigsaw II pada mata pelajaran Dasar Teknik Mesin?

3 Bagaimana kemampuan pemahaman siswa terhadap mata pelajaran Dasar Tenik Mesin setelah melakukan kegiatan pembelajaran melalui model Cooperative Learning tipe Jigsaw II yang tertuang dalam nilai hasil belajar (pre-tes dan posttest)?

\section{LANDASAN TEORI}

\section{A. Konsep Dasar Pembelajaran \\ 1. Pembelajaran}

Tujuan pembelajaran merupakan rumusan perilaku yang telah ditetapkan sebelumnya untuk menjadi milik dan harus nampak dari siswa sebagai akibat dari perbuatan yang telah dilakukan. Tujuan pembelajaran dapat dipilah menjadi tujuan yang bersifat kognitif (pemahaman), afektif (sikap/nilai), dan psikomotorik (keterampilan). Keberhasilan pencapaian tujuan banyak bergantung pada kesiapan dan cara belajar yang dilakukan siswa. Cara belajar ini dapat dilakukan dalam bentuk kelompok ataupun perorangan. (Tim Pengembang MKDK UPI, 2002: 48)

\section{Aktivitas Siswa}

Kunandar (2008:277) mengungkapkan bahwa," Aktifitas siswa adalah keterlibatan siswa dalam bentuk sikap, pikiran, perhatian dalam kegiatan belajar guna menunjang keberhasilan proses belajar mengajar dan memperoleh manfaat dari kegiatan tersebut."

Sejalan dengan itu Sanjaya (2006:13) mengungkapkan bahwa : Keaktifan siswa itu ada yang secara langsung dapat diamati seperti mengerjakan tugas, berdiskusi, mengumpulkan data dan sebagainya, akan tetapi ada juga yang tidak bisa diamati, seperti kegiatan mendengarkan dan menyimak.

Peningkatan aktivitas siswa, diantaranya meningkatkan jumlah siswa yang terlibat aktif belajar, meningkatkan jumlah siswa yang bertanya dan menjawab, meningkatkan jumlah siswa yang saling berinteraksi membahas materi pembelajaran. Metode belajar yang bersifat partisipatoris yang dilakukan guru akan mampu membawa siswa dalam situasi yang lebih kondusif, karena siswa lebih berperan dan lebih terbuka serta sensitif dalam kegiatan belajar mengajar.

Indikator aktivitas siswa yang diungkapkan oleh kunandar (2008:277), dapat dilihat dari :

1. Mayoritas siswa beraktivitas dalam pembelajaran;

2. Aktivitas pembelajaran didominasi oleh siswa;

3. Mayoritas siswa mampu mengerjakan tugas yang diberikan guru melalui pembelajaran kooperatif

\section{Aktivitas Pembelajaran}

Sardiman (2007:100) mengatakan bahwa "Aktifitas belajar adalah aktifitas yang bersifat fisik dan mental seperti seperangkat kegiatan yang dilakukan oleh siswa dalam pembelajaran audiovisual, menulis, dan gambar." Slameto (2003:2) "Belajar adalah suatu proses usaha yang dilakukan sesorang untuk memperoleh suatu perubahan tingkah laku yang baru secara keseluruhan, sebagai hasil pengalamannya sendiri dalam interaksi dengan lingkungannya."

\section{B. Teori Yang Melandasi Pemelajaran Cooperative \\ 1. Proses Belajar Menurut Teori \\ Konstruktivisme}

Paradigma konstrutivisme memandang siswa sebagai pribadi yang sudah memiliki kemampuan 
awal sebelum mempelajari sesuatu. Kemampuan awal tersebut akan menjadi dasar dalam mengkonstruksi pengetahuan yang baru.

Dalam belajar konstrutivisme guru atau pendidik berperan membantu agar proses pengkonstruksian pengetahuan oleh siswa berjalan lancar. Guru tidak mentransferkan pengetahuan yang telah dimilikinya, melainkan membantu siswa untuk membentuk pengetahuannya sendiri. Teori

Konstruktivisme Yang Mendukung Pemelajaran Cooperative

Dilihat dari asal-usul pengetahuan Budiningsih (2005: 98) mengatakan bahwa, "Piagiet cenderung menganut teori psikogenesis, Artinya pengetahuan berasal dari dalam diri individu". Dalam proses belajar, siswa berdiri terpisah dan berinteraksi dengan lingkungan sosial, dan ia mengkonstruksi pengetahuannya lewat tindakan yang dilakukan dengan lingkungan sosialnya.

Dalam penerapan pembelajaran Cooperative Tipe Jigsaw II, siswa dituntut untuk terlibat aktif dalam mengerjakan tugas-tugas. Teori Cooperative Learning (Model Pembelajaran Kooperatif)

\section{Pengertian Cooperative Learning}

Robert Slavin (1995: IX) menjelaskan bahwa "Secara historis cooperative learning telah dikenal sejak lama. Pada saat itu guru mendorong para siswa untuk bekerja sama dalam kegiatan-kegiatan tertentu seperti diskusi atau tutor sebaya". Ini berarti bahwa keberhasilan dalam belajar bukan semata-mata harus diperoleh dari guru saja, melainkan dapat juga dilakukan melalui teman lain yaitu teman sebaya/tutor sebaya.

Anita Lie (2007: 18) mengemukakan bahwa "Pembelajaran kooperatif didefinisikan sebagai strategi belajar kelompok atau sistem belajar kelompok yang terstruktur".

C. Model Pembelajaran Cooperative Learning Tipe Jigsaw II pada Mata Pelajaran Dasar Teknik Mesin.

Jigsaw II dapat digunakan apabila materi yang akan dipelajari adalah yang berbentuk narasi tertulis. Metode ini paling sesuai untuk subjeksubjek seperti pelajaran ilmu sosial, literature, sebagian pelajaran ilmu pengetahuan ilmiah, dan bidang-bidang lainnya yang tujuan pembelajarannya lebih kepada penguasaan konsep daripada penguasaan kemampuan. Pengajaran "bahan baku" untuk jigsaw II biasanya harus berupa sebuah bab, cerita, biografi atau materimateri narasi atau deskripsi serupa. 1

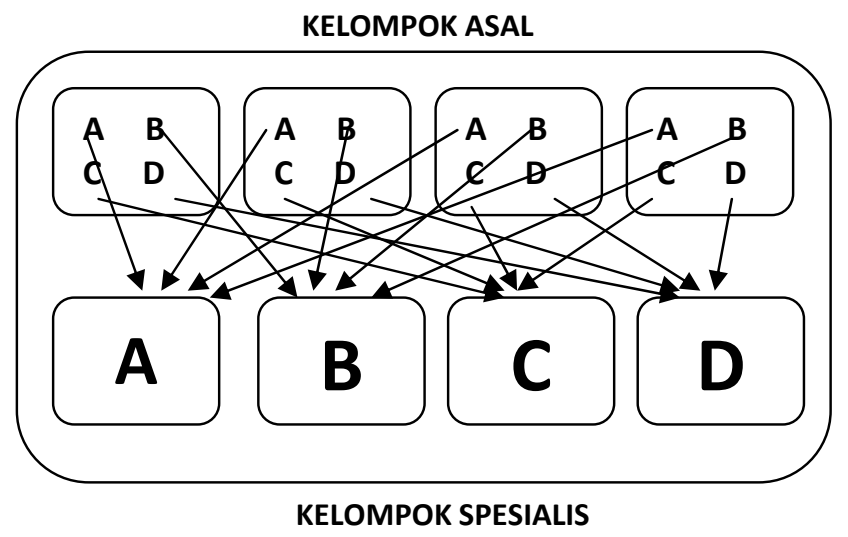

Gambar 2.1 Hubungan antara kelompok asal dan kelompok spesialis Sumber : (Arends, 1997)

\section{Kerangka Pemecahan Masalah}



berikut :

Kerangka pemecahan masalah dan gambaran pola pemecahannya melalui tahapan sebagai

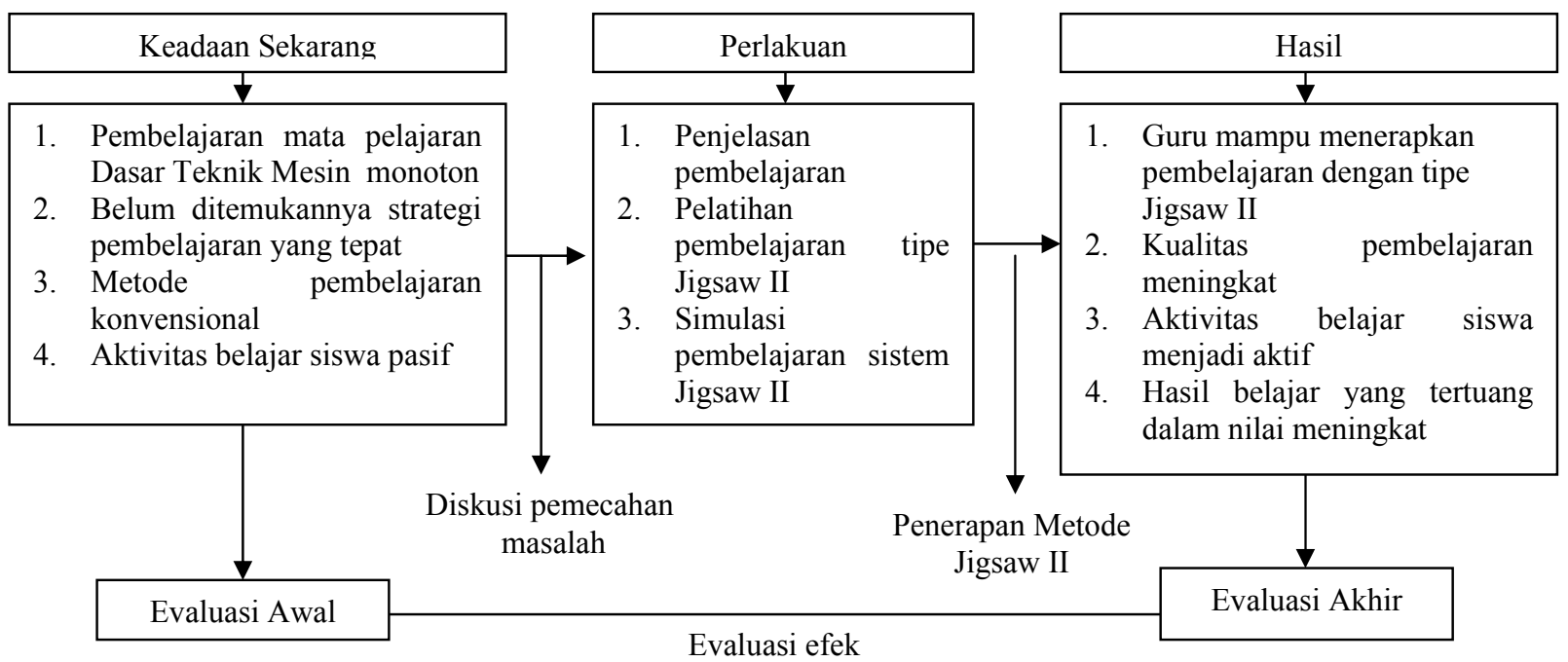

Gambar 2.2. Kerangka Pemecahan Masalah

\section{Mata Pelajaran Dasar Teknik Mesin (DTM)}

Pada penelitian ini, penulis memilih kompetensi dasar memahami komponen poros, bantalan dan kopeling gesek yang merupakan salah satu kompetensi dasar yang termasuk pada mata pelajaran Dasar Teknik Mesin. Materi memahami komponen poros dan aksesorisnya diberikan untuk mendukung mata pelajaran kompetensi kejuruan yang lain seperti pemesinan, serta sebagai dasar pengembangan diri untuk penuangan gagasan merencanakan perhitungan teknik untuk komponen mesin.

\section{METODELOGI PENELITIAN}

\section{A. Metode Penelitian}

Penelitian dalam memecahkan masalah pada proses pembelajaran dengan strategi Cooperative Learning tipe Jigsaw II pada mata Pelajaran Dasar Teknik Mesin terhadap siswa SMK sebagai salah satu solusi seperti yang telah dirumuskan dalam bab pendahuluan, bertujuan mendeskripsikan keadaan dari keseluruhan proses yang terjadi dalam aktivitas pembelajaran. Maka, metode penelitian yang sesuai dengan kebutuhan tersebut adalah metode Penelitian Tindakan Kelas (PTK) atau Classroom Action Research (CAR).

\section{B. Objek Penelitian}

Objek dalam penelitian ini, adalah siswa kelas X TP1 jurusan teknik pemesinan SMK Negeri 6 Bandung pada mata pelajaran Dasar Teknik Mesin Tahun Ajaran 2009-2010 dengan jumlah total 37 orang. Fokus utama penelitian ini terletak pada aspek peningkatan aktivitas dan hasil belajar siswa pada mata pelajaran Dasar Teknik Mesin di SMKN 6 Bandung.

\section{Teknik Pengumpulan Data}

Dalam proses pengumpulan data, data atau informasi yang dibutuhkan dapat diperoleh melalui teknik wawancara, observasi, dan tes. 


\section{HASIL PENELITIAN}

\section{Siklus I}

a. Hasil Belajar

Tabel 4.4.

Data Nilai Pre test Siklus ke-1

\begin{tabular}{|c|c|c|c|c|}
\hline No. & Nilai & Keterangan & Frekuensi & $\begin{array}{c}\text { Prosentase } \\
(\%)\end{array}$ \\
\hline 1 & $90-100$ & Lulus amat baik & - & - \\
\hline 2 & $80-89$ & Lulus baik & 7 & 18.91 \\
\hline 3 & $70-79$ & Lulus Cukup & - & - \\
\hline 4 & $0<70$ & Belum lulus & 30 & 81.08 \\
\hline \multicolumn{3}{|c|}{ Jumlah } & 37 & 100 \\
\hline
\end{tabular}

Tabel 4.5.

Data Nilai Post test Siklus ke-1

\begin{tabular}{|c|c|c|c|c|}
\hline No. & Nilai & Keterangan & Frekuensi & $\begin{array}{c}\text { Prosentase } \\
(\%)\end{array}$ \\
\hline 1 & $90-100$ & Lulus amat baik & - & - \\
\hline 2 & $80-89$ & Lulus baik & 8 & 21.62 \\
\hline 3 & $70-79$ & Lulus Cukup & 13 & 35.13 \\
\hline 4 & $0<70$ & Belum lulus & 16 & 43.24 \\
\hline \multicolumn{3}{|c|}{ Jumlah } & 37 & 100 \\
\hline
\end{tabular}

Secara umum dapat dilihat grafik peningkatan hasil belajar pada siklus ke-1

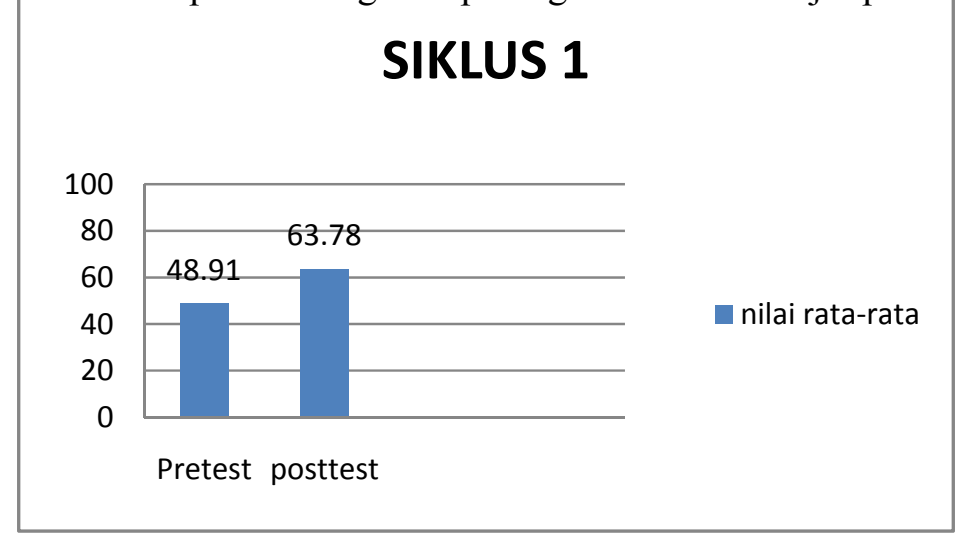

Gambar 4.11. Diagram Nilai Rata-Rata Pre-Test Dan Post-Test Siklus 1

b. N-gain Pada Siklus ke-1

Peningkatan (gain) pada pembelajaran siklus ke-1 memiliki nilai rata-rata 0,24 atau kalau dikategorikan rendah. Artinya, Efektifitas pembelajaran pada siklus ke-1 belum mendapatkan hasil yang diharapkan berdasarkan perbandingan kenaikan pada saat pretest dan posttes dan banyak yang perlu ditingkatkan, direvisi, dan diperbaiki lagi oleh guru dalam hal ini peneliti.

Hal yang dapat disimpulkan dari pelaksanaan siklus I yang tertuang dalam hasil refleksi adalah sebagai berikut:

1. Guru harus menjelaskan kembali teknik pembelajaran cooperative learning tipe jigsaw 
II ini sehingga siswa mengetahui teknik dan cara-cara dalam pelaksanaannya.

2. Dalam penjelasan tujuan pembelajaran guru harus mempertegas materi yang diajarkannya sehingga siswa menjadi antusias untuk memperhatikan dan mengikuti pelajaran dengan sungguh-sungguh

3. Guru harus lebih intensif dalam membimbing kelompok pada saat kegiatan diskusi kelompok spesialis, sehingga pada saat siswa kembali pada kelompok awal, maka informasi yang diharapkan dapat tersampaikan kepada anggota kelompok lain.

4. Guru harus selalu memberikan motivasi dan semangat kepada siswa agar lebih aktif lagi dalam pembelajaran individu maupun pada saat kelompok.

5. Guru harus lebih sering dalam pengutaraan kembali pertanyaan yang di lontarkan siswa jika perlu di beri penekanan agar siswa lain yang kurang menyimak dapat menangkap pertanyaan dan maksud yang dijelaskan oleh guru.

6. Guru harus memberikan apresiasi/pujian/penghargaan kepada kelompok yang telah melaksanakan kegiatan pembelajaran dengan baik, sebagai salah satu bukti nyata memotivasi siswa.

\section{PEMBAHASAN}

\section{Deskripsi Kegiatan}

Berdasarkan fakta yang didapat dari kondisi pelaksanaan tindakan pada siklus I sampai dengan siklus III, guru memberikan bimbingan, menumbuhkan motivasi, membuat suasana belajar siswa dan melakukan pemantauan kegiatan yang dilakukan siswa dalam seluruh tahapan proses pemelajaran mulai dari pembuakaan, penyajian materi sampai kegiatan kelompok, sesuai dengan rencana pemelajaran yang telah dirancang untuk mencapai tujuan pembelajaran. Dari kondisi tersebut terjadi peningkatan setiap siklusnya baik aktivitas yang dilakukan oleh guru maupun aktivitas yang dilakukan oleh siswa. Teknik pengelompokan dalam belajar kooperatif yang dilakukan oleh guru memiliki peran yang penting dalam proses KBM. Siswa belajar dalam kelompok spesialis dan kembali ke kelompok asal dengan membawa informasi dan hasil diskusi dengan penuh rasa tanggung jawab untuk disampaikan kepada teman dalam kelompoknya. Pada siklus I sampai siklus III siswa mendapatkan tugas untuk membahas materi pelajaran kemudian bertemu dan didiskusikan dalam kelompok masing-masing. Peran guru ketika proses kerja kelompok sebagai pembimbing dan fasilitator, kegiatan berpusat pada aktivitas siswa. Setelah proses kerja kelompok kemudian dilanjutkan dengan posttest untuk mengukur kemampuan tiap individu dalam kelompok. Kegiatan pretest dan postes dalam penelitian ini bertujuan untuk mengukur sejauh mana tingkat pemahaman yang diperoleh oleh siswa. Hasil nilai pretes dan posttest menunjukan peningkatan untuk setiap siklusnya. Dari deskripsi diatas jelaslah bahwa desain pembelajaran dengan model cooperative learning tipe Jigsaw II dapat meningkatkan kemampuan pemahaman siswa pada mata pelajaran Dasar Teknik Mesin. Dalam penerapan pembelajaran Cooperative Tipe Jigsaw, siswa dituntut untuk terlibat aktif dalam mengerjakan tugas-tugas. Hal ini dimaksudkan agar siswa dapat terlibat langsung dalam menemukan materi-materi baru bagi dirinya dengan menerapkan keterampilan-keterampilan interpersonal. Sejalan dengan teori Piaget bahwa "perkembangan kognitif akan terjadi dalam interaksi antara siswa dengan kelompok sebayanya dari pada dengan orang-orang yang lebih dewasa" (Budiningsih, 2005: 98). Sehingga dapat disimpulkan bahwa interaksi antara siswa dalam pembelajaran Cooperative akan membantu meningkatkan perkembangan kognitif siswa dalam konteks penelitian ini adalah meningkatnya kemampuan pemahanan siswa pada mata pelajaran Dasar Teknik Mesin.

\section{Aktivitas siswa}


Tabel. 4.17

.Hasil gabungan aktivitas pembelajaran siswa (kelompok "spesialis")

\begin{tabular}{|c|c|c|c|}
\hline \multirow{2}{*}{ Kelompok } & \multicolumn{3}{|c|}{ Hasil Aktivitas PBM Siswa (Kelompok "Spesialis") } \\
\cline { 2 - 4 } & Siklus 1 & Siklus 2 & Siklus 3 \\
\hline 1 & $50 \%$ & $75 \%$ & $83 \%$ \\
\hline 2 & $66 \%$ & $83 \%$ & $100 \%$ \\
\hline 3 & $33 \%$ & $50 \%$ & $75 \%$ \\
\hline 4 & $33 \%$ & $58 \%$ & $83 \%$ \\
\hline 5 & $58 \%$ & $58 \%$ & $75 \%$ \\
\hline 6 & $58 \%$ & $75 \%$ & $100 \%$ \\
\hline Rerata tiap siklus & $44.16 \%$ & $56.83 \%$ & $86 \%$ \\
\hline Kategori per siklus & Sedang & Sedang & Sangat tinggi \\
\hline
\end{tabular}

Tabel 4.18.

Hasil gabungan aktivitas pembelajaran siswa (kelompok "asal")

\begin{tabular}{|c|c|c|c|}
\hline \multirow{2}{*}{ Kelompok } & \multicolumn{3}{|c|}{ Hasil Aktivitas PBM Siswa (Kelompok “Asal”) } \\
\cline { 2 - 4 } & Siklus 1 & Siklus 2 & Siklus 3 \\
\hline 1 & $31.25 \%$ & $68.75 \%$ & $81.75 \%$ \\
\hline 2 & $37.5 \%$ & $62.5 \%$ & $93.75 \%$ \\
\hline 3 & $50 \%$ & $56.25 \%$ & $100 \%$ \\
\hline 4 & $50 \%$ & $56.25 \%$ & $93.75 \%$ \\
\hline 5 & $25 \%$ & $81.25 \%$ & $100 \%$ \\
\hline 6 & $31.25 \%$ & $93.75 \%$ & $93.75 \%$ \\
\hline Rerata tiap siklus & $\mathbf{3 7 . 5 \%}$ & $\mathbf{6 9 . 7 9 \%}$ & $\mathbf{9 3 . 8 3 \%}$ \\
\hline Kategori per siklus & Rendah & Tinggi & Sangat tinggi \\
\hline
\end{tabular}

Hasil analisis data pengamatan aktivitas siswa selama pembelajaran menunjukan bahwa, penerapan model pembelajaran kooperatif tipe jigsaw II dapat meningkatkan aktivitas belajar siswa seperti mendengarkan atau memperhatikan guru pada saat penyajian materi, mencatat hal-hal penting tentang informasi yang didapat pada proses pembelajaran, membaca, mengerjakan tugas, saling kooperatif selama PBM dan menjaga kekompakan dalam belajar serta dalam diskusi sehingga dapat memecahkan masalah dan mempresentasikan kerja kelompok. Hal ini sesuai dengan yang diungkapkan oleh Kunandar (2008: 277) bahwa " Aktivitas siswa adalah keterlibatan siswa dalam bentuk sikap, pikiran, perhatian dalam kegiatan belajar guna menunjang keberhasilan proses belajar mengajar dan memperoleh manfaat dari kegiatan tersebut"

\section{Hasil Belajar}

Selain itu juga penerapan model pembelajaran kooperatif tipe jigsaw II dapat meningkatkan hasil belajar siswa yang tertuang dalam nilai pre-test dan nilai pos-test yang terus mengalami peningkatan dari tiap siklusnya.aktivitas belajar siswa dimulai siklus I, siklus II hingga siklus III terus mengalami peningkatan,hal terebut dapat terlihat dari tabel di bawah ini; 
Tabel.4.19.

Nilai rata-rata Pretest dan Posttes Tiap Siklus

\begin{tabular}{|c|c|c|c|}
\hline Siklus & $\begin{array}{c}\text { Nilai rata-rata } \\
\text { Pretes }\end{array}$ & $\begin{array}{c}\text { Nilai rata-rata } \\
\text { Posttest }\end{array}$ & $\begin{array}{c}\text { Nilai rata-rata } \\
\text { kenaikan }\end{array}$ \\
\hline $\mathbf{1}$ & 48.91 & 63.78 & 14.87 \\
\hline $\mathbf{2}$ & 61.89 & 78.78 & 16.89 \\
\hline $\mathbf{3}$ & 72.56 & 86.89 & 14.33 \\
\hline
\end{tabular}

Dari data diatas dapat kita lihat bahwa perolehan nilai pretest untuk siklus I hanya mendapatkan rata-rata 48.91 (belum lulus), setelah dilakukan penerapan metode pembelajaran kooperatif didapat nilai posttest hanya mendapatkan rata-rata 63.78 atau dengan kata lain hanya mengalami kenaikan 14.87 poin saja. Hal tersebut terjadi karena belum berjalan maksimalnya model pembelajaran kooperatif karena baru pertama kali di terapkan. Pada siklus II terjadi peningkatan dengan nilai rata-rata pretest 61.89 meningkat 16.89 menjadi 78.78 (kategori lulus). Begitupun pada siklus III dengan nilai ratarata pretest 72.56 meningkat 14.33 menjadi 86.89 dan masuk pada kategori lulus amat baik. Di bawah ini adalah diagram kenaikan pretes dan posttest tiap siklusnya.

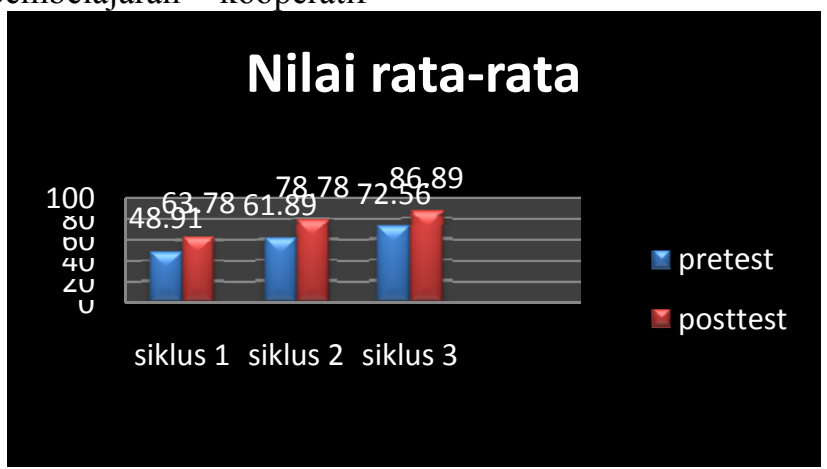

Gambar 4.33. Diagram peningkatan nilai rata-rata pretest dan postes.

Tabel.4.20

Nilai N-Gain tiap siklus

\begin{tabular}{|c|c|c|}
\hline Siklus & Nilai rata-rata N-Gain & Kategori \\
\hline 1 & 0.24 & Rendah \\
\hline 2 & 0.48 & Sedang \\
\hline 3 & 0.58 & Sedang \\
\hline
\end{tabular}

Dari tabel diatas menunjukan nilai Gain ternormalisasi yang menunjukan pengukuran peningkatan penguasaan siswa terhadap materi pembelajaran yang di ukur melalui pre tes dan postes tiap siklusnya. Dengan perolehan nilai gain untuk siklus I sebesar 0.24 (kategori rendah), siklus II terjadi peningkatan 0.24 menjadi 0.48 (kategori sedang), dan untuk siklus III diperoleh NGain 0.58 (kategori sedang).

Dalam kegiatan pembelajaran ini telah nampak kegiatan pembelajaran yang menempatkan siswa sebagai pusat kegiatan belajar mengajar (student centered), sedangkan guru hanya bertindak sebagai fasilitator dan pendorong siswa belajar lebih giat, sesuai dengan indicator aktivitas siswa yang diungkapkan oleh Kunandar (2008:277) yaitu: "pertama, mayoritas siswa beraktivitas dalam pembelajaran; kedua, aktivitas pembelajaran didominasi oleh siswa; ketiga, mayoritas siswa mampu mengerjakan tugas yang diberikan guru melalui pembelajaran kooperatif."

\section{KESIMPULAN}

Berdasarkan analisis data hasil penelitian yang diperoleh di lapangan maka dapat disimpulkan bahwa penerapan model pembelajaran Cooperative Learning Tipe Jigsaw II dapat meningkatkan aktivitas dan hasil belajar siswa pada mata pelajaran Dasar Teknik Mesin pada siswa kelas XTP1 SMK Negeri 6 Bandung. Kesimpulan dari hasil penelitian tersebut dapat diuraikan sebagai berikut:

1. Teknik pengelompokan dalam belajar kooperatif yang dilakukan oleh guru memiliki 
peran yang penting dalam proses KBM. Siswa belajar dalam kelompok spesialis dan kembali ke kelompok asal dengan membawa informasi dan hasil diskusi dengan penuh rasa tanggung jawab untuk disampaikan kepada teman dalam kelompoknya. Peran guru ketika proses kerja kelompok sebagai pembimbing dan fasilitator, kegiatan berpusat pada aktivitas siswa. Sehingga dapat disimpulkan bahwa interaksi antara siswa dalam pembelajaran Cooperative akan membantu meningkatkan perkembangan kognitif siswa dalam konteks penelitian ini adalah meningkatnya kemampuan pemahanan siswa pada mata pelajaran Dasar Teknik Mesin.

2. Aktivitas siswa setelah mengikuti pembelajaran dengan model Cooperative learning tipe jigsaw II pada mata pelajaran Dasar Teknik Mesin terus mengalami peningkatan pada setiap siklusnya hal ini dapat dilihat dari peningkatan aktivitas pada kelompok Asal Siklus I 37.5\% (rendah), kemudian meningkat pada Siklus II $69.79 \%$ (tinggi), dan siklus III 93.83\% (sangat tinggi). Peningkatan aktivitas siswa juga terjadi pada kelompok spesialis yang setiap siklusnya mengalami peningkatan dimulai siklus I $44.16 \%$ (sedang), Siklus II 56.83\% (sedang), dan terus mengalami peningkatan pada siklus III $86 \%$ (sangat tinggi).

3. Peningkatan kemampuan pemahaman siswa terhadap mata pelajaran Dasar Teknik Mesin untuk setiap siklusnya terjadi peningkatan. Temuan yang diperoleh dari penelitian ini adalah adanya hubungan peningkatan aktivitas belajar siswa dengan hasil belajar yang diperoleh melalui pretest dan posttest, hal ini di tunjukan oleh data-data observasi mulai siklus I, siklus II dan Siklus III yang menggambarkan setiap terjadi peningkatan aktivitas belajar diiringi dengan meningkatnya hasil belajar siswa.

\section{SARAN}

Melihat hasil temuan dalam pelaksanaan penelitian ini, diajukan saran-saran kepada:

1. Guru

Model Cooperative Learning Tipe Jigsaw II dapat dijadikan alternatif pembelajaran disekolah dan perlu dipertimbangkan oleh guru untuk dipergunakan, karena model pembelajaran ini selain dapat meningkatkan aktivitas dan kerjasama kelompok siswa dalam kegiatan belajar mengajar juga berpengaruh terhadap peningkatan hasil belajar siswa.

2. Siswa

Bagi siswa yang mendapatkan metode pembelajaran Cooperative Learning Tipe Jigsaw II ini agar dapat mempertahankan aktivitas belajar yang telah baik dan sangat dianjurkan untuk dapat terus meningkatkan dengan cara mengaplikasikannya pada mata pelajaran lain, sebagai metode alternative belajar agar terbentuk rasa tanggung jawab baik individu maupun kelompok.

\section{Peneliti}

Bagi peneliti lain perlu direkomendasikan untuk mencoba penerapan model Cooperative Learning Tipe Jigsaw II terhadap mata diklat produktif lain untuk melihat keberhasilannya.

\section{Sekolah}

Sekolah sebagai lembaga pendidikan agar dapat mendukung dalam setiap penggunaan model pembelajaran, termasuk model pembelajaran Cooperative Learning Tipe Jigsaw II, dan mempertimbangkannya dalam pengembangan kurikulum sebagai alternative model pembelajaran serta memperhatikan penyediaan fasilitas-fasilitas yang diperlukan oleh guru dan siswa untuk melaksanakan proses pembelajaran sehingga dapat meningkatkan kualitas PBM.

\section{DAFTAR PUSTAKA}

Budiningsih, C. Asri. (2005). Belajar dan Pembelajaran. Jakarta: Rineka Cipta.

Isjoni, (2009). Cooperative Learning Efektifitas Pembelajaran Kelompok. Bandung: Alfa Beta.

Kunandar. (2008). Langkah Mudah Penelitian Tindakan Kelas Sebagai Pengembangan Profesi Guru. Jakarta: PT. Raja Grafindo Persada.

Lie, Anita. (2007). Cooperative Learning. Jakarta: Grasindo

Sardiman. (2007). Interaksi dan Motivasi Belajar Mengajar. Jakarta: PT. Raja Grafindo Persada.

Solihatin, E. dan Raharjo. (2007). Cooperative Learning Analisis Model Pembelajaran IPS. Jakarta: Bumi Aksara.

Tim Pengembang MKDK Kurikulum dan Pembalajaran. (2002). Kurikulum Pembelajaran. Bandung: UPI Press.

Trianto. (2007). Model-Model Pembelajaran Inovativ Berorientasi Kontruktivistik. Jakarta: Prestasi Pustaka. 